\title{
EKSPERIMEN PEMBUATAN KARYA PATUNG MENGGUNAKAN ADONAN TEPUNG MAIZENA DI KELAS IX SMP SWASTA BUDI DHARMA TEBING TINGGI TAHUN \\ AJARAN 2015/2016
}

\author{
Risyah Nanda ${ }^{1^{*}}$, Heri Soeprayogi ${ }^{2 *}$ \\ Program Studi Pendidikan Seni Rupa, Jurusan Seni Rupa, Fakultas Bahasa dan Seni \\ Universitas Negeri Medan \\ Email: risyah_nanda@yahoo.co.id
}

\begin{abstract}
ABSTRAK
Risyah Nanda, 2103151026. Eksperimen Pembuatan Karya Patung Berbahan Adonan Tepung Maizena diKelas IX SMP Swasta Budi Dharma Tebing Tinggi Tahun Ajaran 2015/2016. Jurusan Seni Rupa, Fakultas Bahasa Dan Seni UNIMED2016. Penelitian ini bertujuan: (1) Untuk mengetahui keefektifan penggunaan bahan utama tepung maizena dalam pembuatan karya patung, (2) Untuk mengetahui proses pembuatan patung, (3) Untuk mengetahui perbedaan hasil karya seni patung antara menggunakan bahan utama tepung maizena dengan menggunakan bahan utama tanah liat. Penelitian ini dilakukan dilakukan di SMP Budi Dharma Tebing Tinggi. Sampel dalam penelitian ini adalah siswa/siswi kelas IX yang berjumlah 28 Orang. Pengambilan sampel dilakukan dengan purposive sampling. Data penelitian ini dijaring dengan cara eksperimen, observasi dan dokumentasi. Dari hasil penelitian diperoleh kesimpulan bahwa hasil eksperimen pembuatan patung berbahan tepung maizena memiliki bentuk proporsi yangi deal, bentuk yang sesuai dengan tema, dari segi komposisi karya clay ini memiliki tatasusun yang menyangkut keseimbangan, kesatuan, dan keselarasan yang sangat baik, serta dari segi pewarnaan karya clay ini sangat menarik memiliki gelap terang yang sangat baik, kombinasi, kecerahan, kesesuaian warna dengan tema yang baik serta kreatif.
\end{abstract}

Kata Kunci: Eksperimen, Karya, Patung, Tepung 


\section{PENDAHULUAN}

Pengembangan kreativitas di dalam dunia pendidikan pada saat ini masih dirasakan kurang maksimal, karena guru sebagai pendidik kurang bisa dalam membangun stimulus kepada peserta didik untuk mengembangkan kreativitas mereka dan hendaknya guru harus kreatif. Kreatif dalam hal ini yaitu guru dapat mengenalkan tema-tema pembelajaran semenarik mungkin agar pembelajaran yang bertujuan untuk pengembangan kreativitas anak dapat sesuai dengan kebutuhan peserta didik. Selain itu guru mampu memilih materi yang tepat yang dapat merangsang otak anak untuk berkreativitas tidak hanya memberikan tugas kepada siswa dalam pembelajaran Seni Budaya dan Prakarya.

Pendidikan merupakan suatu usaha yang dilakukan untuk membentuk insan yang seutuhnya, yaitu manusia yang beriman, yang bertaqwa kepada Tuhan Yang Maha Esa, berbudi luhur, bertanggung jawab, bekerja keras, disiplin, mandiri, cerdas, terampil, serta sehat jasmani dan rohani. Hal ini selaras dengan tujuan pendidikan Nasional.

Pendidikan seni budaya dan keterampilan sebagaimana yang diamanatkan dalam Peraturan Pemerintah Republik Indonesia Nomor 19 tahun 2005 tentang Standar Nasional Pendidikan tidak hanya terdapat dalam satu mata pelajaran karena budaya itu sendiri meliputi segala aspek kehidupan. Dalam mata pelajaran Seni Budaya dan Keterampilan, aspek budaya tidak dibahas secara tersendiri tetapi terintergrasi dengan seni. Karena itu, mata pelajaran Seni Budaya dan Keterampilan pada dasarnya merupakan pendidikan seni yang berbasis budaya. Konsep pendekatan seni dalam pendidikan adalah program yang mengharapkan anak atau siswa bisa menggambar dalam pendidikan seni rupa bisa bernyanyi dalam pendidikan seni musik, dan bisa menari dalam pendidikan seni tari (Syafii,2002:16). Namun dengan perkembangan waktu pembelajaran seni budaya pada bidang seni rupa tidak hanya mengharapkan siswa pandai dalam menggambar saja melainkan mengharapkan siswa lebih terampil dalam bidang seni rupa secara menyeluruh seperti pandai membuat lukisan, pandai membuat ukiran, dan pandai membuat patung. Seni kaitannya sangat erat di dalam kehidupan anak-anak bahkan orang dewasa karena seni memiliki fungsi sebagai media ekspresi, sebagai media komunikasi, sebagai media berrnain, sebagai media pengembangan bakat dan sebagai media kreativitas.

Pendidikan Seni Budaya dan Keterampilan diberikan di sekolah karena keunikan, kebermaknaan, dan kebermanfaatan terhadap kebutuhan perkembangan peserta didik, yang terletak pada pemberian pengalaman estetik dalam bentuk kegiatan berekspresi/berkreasi dan berapresiasi. Kegiatan anak dalam seni mendorong mereka untuk meningkatkan daya kreativitas yang dimilikinya serta percaya terhadap potensi yang dimilikinya tersebut karena kesempatan untuk berekspresi secara optimal dapat dilakukan melalui seni. 
Tujuan pendidikan seni diberikan kepada anak dengan berbagai tujuan tetapi semuanya didasari oleh keyakinan bahwa seni membentuk kepekaan anak sejak pertama kali mereka mengalaminya sebagai dasar dan ekspresi dan sebagai tanggapan dalam kehidupannya.

Dalam pendidikan Seni Budaya dan Keterampilan, siswa dapat berekspresi, berkreasi, berapresiasi melalui pendekatan belajar dengan seni, belajar melalui seni, dan belajar tentang seni. Pendidikan Seni Budaya dan Keterampilan memiliki peranan dalam pembentukan pribadi peserta didik yang harmonis dengan memperhatikan kebutuhan perkembangan anak dalam mencapai multi kecerdasan yang terdiri atas kecerdasan interpersonal. visual spasial, musical, linguistik, logic matimatik,. naturalis serta kecerdasan adversitas, kecerdasan kreativitas, kecerdasan spiritual dan moral, dan kecerdasan emosional.

Pada bidang keterampilan, diharapkan bisa mencakup segala aspek kecakapan hidup (Life Skills) yang meliputi keterampilan personal, keterampilan vikasional dan keterampilan akademik. Dalam prakteknya berdasarkan ramburambu KTSP, bidang keterampilan ini membekali siswa untuk bisa membuat karya tangan atau pendukung kegiatan seni rupa lainnya.

Mata pelajaran Keterampilan pada tingkat SLTP/SMP ditekankan pada keterampilan vokasional, khusus tangan. Terkait dengan keterampilan tangan, apa yang dapat dilakukan oleh pendidik adalah mengembangkan sikap dan kemampuan peserta didik atau siswa, agar dapat membantu untuk menghadapi persoalan-persoalan di masa mendatang dengan keterampilan dan daya imajinasinya. Pada tingkat SLTP/SMP, ada berbagai jenis karya keterampilan yang memungkinkan untuk dipraktekan di sekolah. Beberapa jenis karya atau kegiatan berkarya keterampilan yang dimaksud adalah patung. Biasanya dalam pembuatan patung bahan yang digunakan adalah berupa tanah liat, kayu, semen dan gypsum. Cara pembuatan patung berbeda-beda sesuai dengan bahan yang digunakan. Seperti pembuatan patung berbahan kayu menggunakan teknik pahat dan pembuatan patung berbahan semen menggunakan teknik cor. Adapula patung yang terbuat dari bahan makanan yaitu terbuat dari campuran tepung kanji dan tepung terigu.

Seni patung adalah cabang seni rupa yang hasil karyanya berwujud tiga dimensi. Diciptakan dengan cara memahat, membentuk (misalnya dengan bahan tanah liat) atau mencetak (dengan cetakan). Seiring dengan perkembangan seni patung modern, karya-karya seni patung menjadi semakin beragam, baik bentuk maupun bahan dan teknik yang digunakan, sejalan dengan perkembangan teknologi serta penemuan bahan-bahan barn.

Pada daerah-daerah tertentu patung memiliki fungsi masingmasing contohnya di Bali patung digunakan untuk ritual dalam upacara keagamaan. Patung juga banyak digunakan sebagai monumen yang mengabadikan peristiwa penting atau menghormati tokoh, 
terutama pejuang kemerdekaan. Di Sekolah Menengah Pertama seni patung dapat dipelajari bagaimana cara pembuatan dan sejarah pada pelajaran Seni Rupa.

Pada Sekolah Menengah

Pertama Budi Dharma para siswa setiap tahunnya membuat karya seni patung dengan menggunakan bahan tanah liat. Berdasarkan hasil wawancara peneliti dengan beberapa siswa bahwa pembuatan patung dengan bahan utama tanah liat sulit untuk didapatkan. Hal ini disebabkan karena tidak semua tanah liat yang mereka peroleh dapat digunakan sebagai bahan utama pembuatan patung.

Berdasarkan pengamatan peneliti guru masih cenderung memberikan metode cerama dalam penyampaian proses pembuatan patung sehingga siswa merasa kesulitan dalam mempraktekan pembuatan patung. Adapun bahanbahan yang digunakan yaitu air, tanah liat. dan meja putar. Proses membuat patung menggunakan tanah liat yaitu campurkan tanah liat dengan air sedikit demi sedikit sambil diaduk-aduk sampai tanah menyatu tetapi tidak terlalu lembek supaya mudah dibentuk, setelah terbentuk rapikan dengan cara dielus menggunakan jari dan bantuan air sampai menjadi halus. Dengan penggunan tanah liat sebagai bahan utama pembuatan patung kurang efektif didalam kelas karena membuat keadaan kelas menjadi kotor dan tidak nyaman untuk belajar ketika pergantian mata pelajaran. Selain itu, penggunaan tanah liat sebagai bahan pembuatan patung membutuhkan waktu lama dalam proses pengeringan hasil karya patung dan pemberian warna juga sulit dilakukan.

Untuk mencari pemecahan dan permasalahan ini dapat dilakukan dengan menggunakan bahan utama lainnnya. Salah satu bahan yang dapat digunakan adalah tepung. Pembuatan patung menggunakan tepung sangat mudah dipraktekkan karena tepung mudah diperoleh, adapun bahan-bahan yang digunakan untuk membuat patung berbahan dasar tepung yaitu tepung tapioka, tepung beras, tepung maizena, benzoate, lem putih, baby oil dan cat poster. Cara membuat patung dengan bahan utama tepung yaitu dengan mencampurkan ketiga macam tepung dan benzoate, masukan lem putih kemudian uleni sampai kalis, campurkan minyak baby (baby oil) agar adonan tidak lengket di tangan, simpan dalam plastik yang dilaminating atau ditutup rapat, kemudian campurkan adonan patung yang sudah jadi dengan warna yang diinginkan, aduk-aduk sampai semua warna tercampur rata, dan bungkus adonan dengan plastik supaya tidak kering.

Dengan adonan patung tepung dapat membuat aneka kreasi sesuai imajinasi atau keinginan. Karena bahan patung tepung bahan yang murah dan mudah didapat di pasaran, kreativitas dalam mengolah patung tepung juga tidak membutuhkan peralatan yang mahal sehingga patung berbahan patung tepung akan menghasilkan karya seni patung yang beraneka ragam dan miniatur patung dapat didesain sangat mirip dengan aslinya.

Berdasarkan latar belakang masalah di atas peneliti tertarik untuk melakukan eksperimen dalam 
pembuatan karya patung dengan bahan utama tepung maizena. Karena bahan ini mudah didapatkan maka peneliti membuat judul penelitian ini berupa "Eksperimen Pembuatan Karya Patung Menggunakan Adonan Tepung Maizena di Kelas IX SMP Swasta Budi Dharma Tebing Tinggi Tahun Ajaran 2015/2016".

\section{Kajian Pustaka}

\section{Kerangka Teoritis}

\section{Pengertian Ekperimen}

Proses pembelajaran
menuntut guru dalam merancang
metode pengajaran yang
memungkinkan terjadinya proses
pembelajaran bagi siswa untuk
mencapai tujuan belajar baik dari
segi kognitif, afektif ( sikap) dan
psikomotorik (keterampilan).
Membuat suatu rancangan metode
pembelajaran merupakan acuan dan
panduan baik bagi guru itu sendiri
maupun bagi siswa. Dalam penelitian
ini metode mengajar yang digunakan
yaitu dengan menggunakan metode
eksperimen sebagai alternatif strategi
dalam mencapai tujuan
pembelajaran.

$$
\text { Djamarah }
$$

berpendapat, "Metode eksperimen adalah cara penyajian pelajaran dimana siswa melakukan percobaan dengan mengalami dan membuktikan sendiri sesuatu yang dipelajari”. Sedangkan menurut Roestiyah (2008:80) mengutarakan, "Metode eksperimen adalah salah satu cara mengajar dimana siswa melakukan suatu percobaan tentang suatu hal, mengamati prosesnya dan menuliskan hasil percobaannya serta mampu mengambil kesimpulan".
Menurut Sagala (2010:220) metode eksperimen adalah cara menyajikan bahan pelajaran dimana siswa melakukan percobaan dengan menalami untuk membuktikan sendiri suatu pertanyaan atau hipotesis yang dipelajari. Roestiyah N.K (2001:80) menyatakan bahwa metode eksperimen adalah suatu cara mengajar, dimana siswa melakukan suatu percobaan tentang suatutu hal, mengamati prosesnya serta menuliskan hasil percobaan, kemudian hasil pengamatan ini disampaiakn ke kelas dan dievaluasi oleh guru.

Menurut Winataputra (1998:20) karakteristik metode eksprimen serta hubungannya dengan pengalaman belajar siswa antara lain : (a) Ada alat bantu yang digunakan, (b) siswa aktif melakukan percobaan, (c) guru membimbing, (d) tempat dikondisikan , (e) membangkitkan rasa ingin tahu siswa, (f) menerapkan konsep informasi ari eksperimen.

Menurut Rusyan (1993:94) tujuan metode eksperimen yaitu : (1) mengembangkan keterampilan pemecahan masalah melalui identifikasi masalah, pengumpulan dan penafsiran data, serta penarikan kesimpulan, (2) metode eksperimen adalah salah satu cara mengajar dimana penyajian bahan pelajaran menuntut keaktifan siswa untuk mempelajari, mencari, mengamati, dan mengenal sesuatu materi yang dipelajari melalui proses percobaanpercobaan yang dilakukannya, melalui kegiatan itu siswa dapat merekam dalam ingatannnya secara langsung tentang sebuah proses sehingga mampu dalam mengambil suatu kesimpulan.mengembangkan 
kebiasaan dan keterampilan mendayagunakan alat-alat laboratorium, (3) membentuk dan mengembangkan kebiasaan mencatat data secara teratur, mengembangkan dan membentuk sikap-sikap ilmiah pada siswa, (5) belajar menggunakan metode ilmiah pada siswa, (6) mengembangkan rasa percaya diri dan tanggungjawab bagi setiap siswa, (7) menemukan caracara menyelidiki sesuatu yang baru, sehingga meningkatkan minat siswa pada masalah-masalah sains.

$$
\text { Sagala ( 2010:220-221) }
$$

mengemukakan bahwa metode eksperimen memiliki kebaikan dan kelemahan. Adapun kebaikan metode eksperimen yaitu: (1) metode ini akan membuat siswa lebih percaya atas kebenaran atau kesimpulan berdasarkan percobaannya sendiri daripada hanya menerima kata guru atau buku saja, (2) dapat mengembangkan sikap untuk mengadakan studi eksploratis tentang sains dan teknologi, suatu sikap dari seorang ilmuan.

Sedangkan kelemahan
metode eksperimen yaitu: (1)
pelaksanaan metode ini sering
memerlukan berbagai fasilitas
peralatan dan bahan mutakir.

Eksperimen-merupakan

modifikasi kondisi yang dilakukan secara sengaja dan terkontrol dalam menentukan peristiwa atau kejadian, serta pengamatan terhadap perubahan yang terjadi pada peristiwa itu sendiri (Moch. Ali, 1993:134)

Eksperimen bertujuan (Zuriah, 2006: 58): a. Menguji hipotesis yang diajukan dalam penelitian.

b. Memprediksi kejadian atau peristiwa di dalam latar eksperimen.

c. Menarik generalisasi hubungan antar variabel

Berdasarkan beberapa pendapat yang telah dikemukakan diatas, maka dapat disimpulkan bahwa: Metode eksperimen adalah cara mengajar dimana peneliti melakukan suatu percobaan, mengamati prosesnya, gejala dan menuliskan hasil percobaannya serta mampu mengambil kesimpulan dari percobaannya.

\section{Hakekat Seni Patung}

Seni patung sudah muncul sejak zaman lampau. Di Sumeria (Mesopotamia) ditemukan peninggalan patung tanah liat yang dibuat pada 1415 SM. Di Tell Asmar ditemukan patung gips putih yang diberi warna hitam peninggalan tahun 2600 SM. Hal ini menunjukkan seni patung telah mengarungi sejarah yang panjang.

Seni patung adalah bagian seni murni dalam bentuk karya seni tiga dimensional atau trimatra, meskipun ada juga karya seni patung konvensional terdapat berbagai teknik glyptic, yang berarti pahatpahat atau membentuk patung dengan cara mengurangi bahan dasar sampai terbentuk patung yang dikehendaki bahari (2008:83).

Di zaman modern, patung banyak digunakan sebagai media ekspresi dan kegiatan spiritual. Perkembangan patung di zaman modern meliputi aspek teknik, bahan, maupun bentuk. Pembuatan patung 
zaman Mesir kuno selalu berhubungan dengan pembangunan tempat-tempat sacral lainnya. Biasanya patung Mesir merupakan tradisi pengulangan (stereotipe) dari patung yang pernah ada.

Dari sejarah patung yang dipaparkan di atas maka dapat disimpulkan bahwa seni patung adalah pembabaran ekspresi, ide, dan gagasan ke dalam karya seni rupa tiga dimensi yang semakin lama akan terus berkembang. Baik perkembangan modelnya maupun perkembangan didalam pemakaian bahan.

Karya patung modern saat ini mulai berkembang pesat seiring dengan kebutuhan dalam mengarungi perubahan gaya hidup di lingkungan kita. Menurut ensiklopedia Indonesia (1990:25) seni payung sculpture berarti seni pahat atau bentuk benda yang padat yang diwujudkan dalam tiga dimensional yang ciptaannya bisa berupa gambar-gambar timbul (relief) atau patung yang dibuat dari media kayu maupun logam.

Menurut Mikke Susanto (2011:296) seni patung adalah sebuah tipe karya tiga dimensi yang bentuknya dibuat dengan metode subtraktif (mengurangi bahan seperti memotong, mematahkan ) atau aditif ( membuat model lebih dulu seperti mengecor dan mencetak ). Sedangkan menurut B.S Myers (1958:131-132) mendefinisikan seni patung adalah karya tiga dimensi yang tidak terikat pada latar belakang apapun atau bidang apapun pada suatu bangunan. Selain itu Myers (1969:351) menambahkan bahwa seni patung berdiri sendiri dan memang benar-benar berbentuk tiga dimensi sehingga dari segi manapun kita melihatnya akan dihadapkan kepada bentuk yang bermakna.

Menurut Soenarso dan Soeroto (1996:6) Seni patung adalah semua karya dalam bentuk meruang. Sedangkan menurut Kamus Besar Indonesia adalah benda tiruan, bentuk manusia, hewan yang cara pembuatannya dengan di pahat.

Berdasarkan pengertian di atas dapat disimpulkan bahwa karya seni memiliki media peranan yang sangat kuat. Segala hal mampu menjadi aspek pendukung dalam terciptannya karya seni, yang perwujudan salah satunya adalah karya seni patung. Cabang seni rupa tiga dimensi ini merupakan perwujudan ekspresi dan kreasi manusia.

Ada beberapa macam cara untuk membuat patung diantaranya :

(1) Asembling ( merakit )

Membuat sebuah komposisi dari bermacam-macam material sperti found, objek, kertas, kayu dan tekstil.

(2) Curving ( memahat )

Memahat adalah sebuah teknik subraktif, artinya mengurangi material sampai memperoleh bentuk akhir patung. Material yang digunakan dalam metode ini adalah: batu-batuan, kayu, cor semen, dan material kersa lainnya. Alat-alat yang digunakan untuk global: kampak, golok, gergaji, chain saw ( gergaji mesin ), dan lain-lain. Untuk detail pahat ( kayu dan batu ), kikir, pasha, dan lain-lain. Untuk Finishing: amplas, slab, furnishing, cat dan lain-lain. 
(3) Modeling

Adalah proses additive ( menambah ), dimana material dibangun menuju ke bentuk akhir patung, maerial ini harus lentur, seperti tanah liat, lilin, plaster, dan pematung menggunakan tangannya untuk membentuk. Pada perkembangannya bisa dibantu alat seperti butsir.

(4) Mengecor

Teknik mengecor atau mencetak adalah teknik yang dipakai jika media yang digunakan bersifat cairan. Sebelum mengecor seorang pematung harus membuat cetakan terlebih dahulu. Untuk mendapat cetakan, pematung harus membuat model patung jadi atau model positif, setelah itu pematung membuat cetakan negatif. Bahan yang digunakan untuk membuat patung berbeda dengan bahan untuk membuat cetakannya. Contohnya, jika bahan yang digunakan untuk membuat patung adalah logam, maka bahan untuk membuat cetakannya adalah gips atau tanah liat.

(Sumber:

https://brainly.co.id/tugas/105 5449).

(5) Kinetik

Sedangkan dikutip dari buku Diksi Rupa, yang dimaksud kinetic art atau seni kinetic atau patung bergerak (sculpture in motion) menurut $\mathrm{R}$ Mayer, kinetic art mengarah pada karya seni yang menkonstruksikan elemen bergerak dengan sumber tenaga, bisa artifisial (buatan) maupun ilmiah.

(Sumber:http://nunukambarw ati.blogspot.co.id/2015/08/ku mbang-kinetik.html)

Ada beberpa media dalam pembuatan patung seperti menurut G. Shidarta (1987) media seni patung adalah berupa bahan, alat, dan teknik yang diperlukan dalam pembuatan seni patung. Bahan tersebut diantaranya:

a. Bahan lunak

Material yang digunakan empuk dan mudah dibentuk. Misalnya tanah liat, plastisin dan sabun, vinil, keret, resin, latex, plastic, kawat, kanvas, kapuk

b. Bahan sedang

Material yang tidak lunak dan tidak keras. Misalnya kayu waru, kayu sengon, kayu randu dan kayu mahoni.

\section{c. Bahan keras}

Material dapat berupa kayu atau batu - batuan. Contohnya kayu jati, kayu ulin, batu granit, batu andesit dan batu marmer, tembaga, perunggu

(Sumber:

http://senipandai.blogspot.co.id/2015 /11/macam-macam-seni-patungyang-harus.html)

Pemilihan jenis media pada dasarnya dapat disesuaikan dengan selera, kebutuhan, dan anggaran masing-masing. Pada penelitian di SMP Swasta Budi Dharma peneliti memilih menggunakan patung yang terbuat dari tepung dikarenakan selain hargany terkjangkau dan mudah didapat di toko-toko, patung 
dari tepung adalah media yang aman digunakan sebagai media bermain

Menurut Stephani (2011:85) patung dalah seni mebuat aneka bentuk benda dari adonan tepung. Bahannya berupa tepung beras, maizena, dan tepung tapioka yang dicampur menjadi satu, diaduk dengna lem dan pewarna, kemudian adonan siap dibentuk menjadi apa saja, mulai dari miniatur aneka benda dan binatang hingga hiasan pada cermin.

$$
\text { Patung dalam arti }
$$
sesungguhnya dalah tanah liat, namun selain terbuat dari tanah liat, patung juga terbuat dari bermacammacam bahan tetapi adonannya memiliki sifat seperti patung (liat/dapat dibentuk). Tanah liat dihasikan oleh alam, yang berasal dari pelapukan kerak bumi yang sebagian besar tersusun oleh bantuan feldspatik, terdiri dari batuan granit dan batuan beku.

Saat ini tanah liat atau lempung sudah jarang ditemukan. Selain jarangnya tanah liat ini bisa ditemukan, dulu jika akan membuat hasil kreasi berbahan tanah liat kita harus rela untuk menyatu dengna pekatknya tanah liat yang kotor. Semakin berkembangnya zaman, sekarang tanah liat dapat digantikan dengan menggunakan bahan lain dengan tekstur yang sama dengan tanah liat. Saat ini patung dibuat dengan bahan yang mudah didapat dan bersih dari kotoran sehingga aman untuk anak-anak.

\section{Pengertian Patung Tepung}

Menurut stephian
berkreasi $2011: 2)$
mengingatkan kita pada
bermain dengatung
kengan lilin mainan.

Bedanya lilin mainan sudah mempunyai warna dan tidak bisa mengeras. Sementara patung yang terbuat dari bahan lain atau adonan ( tepung, roti, bubur kertas) bisa kita beri warna dan bisa mengeras. Fisiknya lentur dan halus, membuatnya mudah dibentuk menjadi apaa saja.

Patung tepung merupakan jenis patung yang cukup murah karena menggunakan bahan-bahan yang mudah dicari dengan harga yang terjangkau. Menurut stephani (2011:10) terdapat bahan untuk membuat patung berbahan dasar tepung, antara lain: (1) 100 gram tepung tapioka, (2) 100 gram tepung beras, (3) tepung maizena, (4) $2 \mathrm{sdm}$ benzoat, (5) 300 gram lem PVAc/lem putih, (6) minyak bayi (baby oil) secukupnya, dan (7) cat poster/cat akrilik.

Cara membuatnya yaitu: (1) campur ketiga macam tepung dan benzoat, (2) masukkan lem PVAc/lem putih kemudian uleni sampai kalis, (3) campurkan minyak bayi (baby oil) agar adonan tidak lengket di tangan, (4) simpan dalam plastik yang dilaminating atau ditutup rapat, (5) campurkan adonan patung yang sudah jadi dengan warna yang diinginkan, (6) adukaduk sampai semua warna tercampur rata, dan (7) bungkus adonan dengan plastik supaya tidak kering.

Ada beberapi tip yang harus diperhatikan dalam pembuatan dan pewarnaan adonan patung dari tepung, diantaranya: (a) pakailah tepung yang masih bagus dan jangan memakai tepung yang sudah kadaluwarsa, (b) gunakanlah minyak bayi (baby oil), jangan gunakan minyak goreng, (c) gunakan lem 
PVAc/lem putih yang kental dan tidak cair, (d) ukuran lem harus pas dan jangan dikurangi, karena hasil patung akan retak, (e) bila adonan agak kering, tambahkan sedikit air kemudian diuleni kembali, (f) adonan patung yang sudah agak kering, jangan dipaksakan untuk dibentuk, karena permukaan patung yang dihasilkan akan retak, sebaiknya ditambahkan sedikit air, dan cat poster atau cat akrilik. Jangan menggunakan pewarna makanan, karena kan menimbulkan jamur, pakai pewarna yang kental agar hasil adonan tidak terlalu lembek, (h) jika ingin membuat warna pastel, adonan harus dicampur dengan cat putih agar warnya tidak kusam, (i) jika ingin membuat warna putih, adonan juga tetap dicampur dengan cat putih agar setelah kering warna patung tidak kusam.

Berkreasi seni rupa tida dimensi bagi anak SMP dapat diberikan pengenalan praktek membentuk (mematung). Kegiatan membentuk atau mematung dilakukan dengan cara mengubah suatu bahan antara lain berupa adonan, balok plastisin menjadi suatu bentuk/ model mainan, patung yang wujudnya tiga dimensi, atau relief timbul. Sumanto (2006:127) menyatakan bahwa melalui kegiatan membentuk diharapkan dapat mengembangkan kompetensi rasa seni, ketelatenan, kecekatan, kreativitas anak SMP secara bebas.

\section{Kerangka Berfikir}

Kreativitas merupakan tujuan utama dif dalam menghasilkan karya seni. Karya alam pembelajaran Seni Budaya, dengan proses beajar siswa bisa melatih diri untuk mengembangkan kreativitas yang mereka miliki dengan bimbingan guru. Kemmapuan berkreativitas dalam seni diartikan sebagai kemampuan menampilkan ide-ide baru. Dalam pendidikan perlu diasah pola pikir siswa gara menjadi lebih kreatif dalam menghasilkan karya seni. Karya tangan merupakan karya seni yang diolah oleh kecepatan, kecekatan seseorang dan inovasi dalam berkarya.

tangan dan kesenian merupakan kegiatan membantu perkembangan abak dalam mengembangkan segala potensi yang dimilikinya, baik meupakan ungkapan, dorongan, keinginan, pikiran, dan harapan atau gagasan lain yang merupakan hasil interaksi antar manusia dan lingkungannya (kebudayaan).

Karya seni patung adalah sebuah tipe karya tiga dimensi yang bentuknya dibuat dengan metode subtrkatif ( mengurangi bahan seperti memotong, menatah ) atau aditif ( membuat model lebih dulu seperti mengecor dan mencetak). Untuk memudahkan siswa dalam pembuatan seni patung dapat menggunakan tepung, sangat mudah diperoleh dan proses pengolahan yang tidak rumit, hal ini memudahkan siswa dalam pembuatan karya seni patung.

Langkah utama dalam pembuatan patung adalah pemilihan bahan dasar berupa tepung, kemudian untuk mengawetkan bahan dasar dicampur dengan pengawet makanan. Langkah kedua, untuk membuat patung menjadi lebih pulen atau liat dicampur dengan lem seperti lem fox. Langkah ketiga adalah proses pembuatan patung. Langkah keempat adalah finishing. Adapun 
dasar utama yang harus diketahui oleh siswa adalah desain dalam pembuatan patung yang akan dibuat. Hal ini akan memudahkan siswa dalam proses pembuatan.

Melalui langkah-langkah dan bahan utama tepung ini, siswa diharapkan tidak mengalami kesulitan dalam mencari media atau bahan pembuatan patung, dapat memungkinkan seluruh siswa paham dalam proses pembuatan tepung hinga menjadi tangan patung.

\section{METODELOGI PENELITIAN}

\section{Tempat dan Waktu Penelitian}

\section{Lokasi}

Penelitian ini dilaksanakan di SMP Swasta Budi Dharma Tebing Tinggi. Peneliti memilih sekolah ini karena di sekolah ini belum pernah diadakan penelitian yang sama pada pokok bahasan patung dengan bahan tepung.

\section{Jadwal}

Penelitian Penelitian ini direncanakan akan dilakukan mulai bulan Oktober hingga Desember 2015 tahun pembelajaran 2015/2016.

\section{Populasi dan Sampel Penelitian}

\section{Populasi}

\section{Sugiyono}

(2011:117)

mengatakan : populasi adalah wilayah generalisasi yang terdiri atas: obyek/subyek yang mempunyai kualitas dan karakteristik tertentu yang ditetapkan oleh peneliti untuk dipelajari dan kemudian ditarik kesimpulannya.
S. Margono (2005:118) berpendapat : populasi adalah seluruh data yang menjadi perhatian kita dalam suatu ruang lingkup dan waktu yang kita tentukan. Jadi populasi berhubungan dengandata, bukan manusianya.

Menurut Arikunto (2009:130) "Populasi adalah keseluruhan subjek penelitian. Apabila seseorang ingin semua elemen yang ada dalam wilayah penelitian, maka penelitian merupakan penelitian populasi atau studi sensus".

Dari ketiga pendapat di atas dapat ditarik kesimpulan populasi adalah jumlah dari keseluruhan pada objek penelitian. Adapun populasi dalam penilitian ini yaitu seluruh siswa kelas IX SMP Swasta Budi Dharma Tebing Tinggi yang terdiri dari 2 kelas dengan rincian sebagai berikut :

Tabel 3. 1 Populasi Siswa

KELAS IX SMP SWASTA BUDI

DHARMA TEBING TINGGI

TAHUN PEMBELAJARAN 2015/2016.

\begin{tabular}{|c|c|c|}
\hline No & Kelas & $\begin{array}{c}\text { Jumlah } \\
\text { Siswa }\end{array}$ \\
\hline 1. & IX A & 35 \\
\hline 2. & IX B & 35 \\
\hline
\end{tabular}

\section{Sampel}

$$
\text { Sugiono }
$$

(2011:118)

berpendapat : Sampel adalah bagian dari jumlah dan karakteristik yang dimiliki oleh populasi tersebut. Bila populasi besar, dan peneliti tidak inungkin mempelajari seinua yang ada pada populasi, misalnya karena 
keterbatasan dana, tenaga dan waktu, maka peneliti dapat menggunakan sampel yang diambil dari populasi itu. Apa yang dipelajari dari sampel itu, kesimpulannya akan dapat diberlakukan utuk populasi. Untuk itu sampel yang diambil dari populasi harus betul-betul representatif (mewakili).

$$
\text { Di dalam Kamus Besar }
$$

Bahasa Indonesia, (2014:742) menjelaskan: sampel adalah sesuatu yang dipergunakan untuk menunjukkan sifat suatu kelompok yang lebih garis besar.

Dari pendapat di atas dapat disimpulkan bahwa sampel adalah sebagian dari jumlah populasi atau yang mewakili dari populasi yang akan diteliti. Dalam pengambilan sampel, peneliti menggunakan tehnik purposive sampling, yaitu pengambilan sampel yang disesuaikan dengan konsep yang telah ditentukan dan sesuai dengan kebutuhan penelitian. Sampel dari penelitian ini yaitu kelas IX B sebagai sampel penelitian.

\section{Metode Penelitian}

Untuk memperoleh kebenaran terhadap basil penelitian serta menghindari terjadinya kesalahan dalam penelitian diperlukan suatu metode yang sesuai dengan masalah dan tujuan penelitian. Metode penelitian pada dasarnya merupakan cam ilmiah untuk mendapatkan data dengan tujuan dan kegunaan tertentu (Sugiyono, 2010:2).

Penggunaan metode yang tepat akan memberikan hasil yang baik dan akan tercapai tujuan untuk menjawab hipotesis yang telah dirumuskan. Oleh karena itu, metode penelitian memegang peranan yang sangat penting dalam sebuah penelitian. Hal ini sejalan dengan pemyataan Arikunto yang mengatakan bahwa, "Metode penelitian merupakan struktur yang sangat penting karena berhasil tidaknya, ataupun tinggi rendahnya kualitas basil penelitian sangat ditentukan oelh ketepatan dalam memilih metode penelitian.

Metode penelitian yang digunakan oleh peneliti dalam mengumpulkan data menggunakan metode penelitian eksperimen (experimental research). Metode eksperimen adalah suatu cara untuk mencari hubungan sebab akibat antara dua faktor yang sengaja ditimbulkan peneliti. Eksperimen selalu dilakukan dengan maksud untuk melihat akibat suatu perlakuan( Arikunto,2006:3). Metode penelitian digunakan untuk melihat proses pembuatan patung dengan bahan yang berbeda dari yang mereka pakai yaitu menggunakan tepung maizena oleh siswa kelas IX SMP Swasta Budi Dharma Tebing Tinggi.

\section{Desain Penelitian}

Penelitian ini menggunakan metode eksperimen dengan rancangan quasi eksperimen. Dengan melakukan eksperimen didalam kelas yang sudah tersedia sebagaimana adanya tanpa melakukan perubahan situasi kelas dan jadwal pembelajaran. Perlakuan yang dilaksanakan adalah proses 
pembuatan patung menggunakan bahan utama tepung maizena.

\section{Jalan Operasional}

Penelitian ini dilakukan dengan cara sebagai berikut:

a) Menentukan kelas yang dijadikan subjek penelitian.

b) Memperkenalkan berbahan tepung maizena.

c) Mengajarkan cara pembuatan berbahan tepung maizena.

d) Siswa melakukan praktek pembuatan tepung maizena.

e) Mengevaluasi bentuk, wama, dan komposisi pada hasil praktek tepung maizena.

f) Hasil tepung maizena yang diteliti.

\section{Teknik Pengumpulan Data}

Teknik pengumpulan data merupakan suatu cara yang dilakukan peneliti dalam mengumpulkan data untuk dijadikan sebagai sampel penelitian. Dalam usaha mengumpulkan data, peneliti menggunakan teknik observasi. Teknik observasi, yaitu cara pengumpulan data dengan melakukan pengamatan langsung dan pencatatan terhadap objek.

Dalam penelitian ini teknik pengumpulan data yang akan digunakan sebagai berikut:

\section{Observasi}

Di dalam Kamus Besar Bahasa Indonesia, (2014:605) observasi adalah pengamatan. peninjauan secara cermat dan mengamati secara teliti.

Observasi merupakan cara yang dominan dalam penelitian deskriptif kualitatif, sehingga dengan mengadakan pengamatan langsung kita lebih mengetahui apa yang sedang dihadapi. Maka sesuai dengan tujuan penelitian ini, penulis langsung mengamati karya patung siswa SMP kelas IX, SMP Swasta Budi Dharma Tebing Tinggi. Menurut Ali (1982-82) yakni "Penilitian yang dilakukan dengan cara mengadakan pengamatan terhadab objek, baik secara langsung maupun tidak langsung, menggunakan teknik yang disebut pengamatan atau observasi".

Maka disimpulkan bahwa observasi merupakan pengamatan langsung yang dilakukan terhadap objek yang akan diamati atau diteliti yang mencakup aspek yang terlingkup dalam objek, objek yang dimaksud penelitian ini yaitu;

teknik pembuatan benda, peralatan yang digunakan, dan penilaian terhadap unsur warna, bentuk dan komposisi.

\section{Dokumentasi}

Dokumentasi yang dimaksud dalam penelitian ini adalah dokumentasi objek penelitian berupa foto dengan cara memotret objek yang akan diteliti. Dokumentasi dilakukan untuk mendapat gambaran hasil karya siswa kelas IX Swasta Budi Dharma Tebing Tinggi. Analisis hasil karya patung degan melihat teknik pembuatan, selanjutnya penilaian dilakukan uji validasi pakar, tujuannya untuk memperbaiki tampilan daftar, untuk pengembangan aspek tujuan dan pengukuran, serta pedoman penilaian. Data ini diperoleh dari tiga orang penilai dengan lembaran 
penilaian yang sama. Adapun ketiga penilai yang dimaksud adalah :

a) Betty E.S Pangaribuan, S.Pd ( guru bidang Seni Rupa SMP Swasta Budi Dharma).

b) Drs. Mesra, M.Sn (dosen Seni Rupa Universitas Negeri Medan).

c) Drs.Misgiya, M.Hum (dosen Seni Rupa Universitas Negeri Medan).

Penilai terdiri dari dua orang dosen seni rupa dan satu orang guru seni rupa. Ketiga orang tersebut dipilih dengan alasan; untuk mengurangi unsur subjektif dalam hal penilaian, dan mendapatkan validitas dan kredibilitas basil penilaian. Penilai tersebut diyakini sudah memiliki kepekaan estetis yang baik dalam menilai hasil karya khususnya tangan.D. Teknik Analisis Data

Teknik analisis data adalah suatu teknik yang digunakan untuk menentukan dan merupakan suatu penjelasan tentang sesuatu yang ada dalam penelitian. Adapun teknik penelitian data yang digunakan adalah deskriptif kualitatif yaitu menguraikan teori dan data yang diperoleh melalui pengumpulan data dari lapangan. Data yang diperoleh dianalisis dengan langkah-langkah sebagai berikut :

1. Mengevaluasi dan mendeskripsikan secara kualitatif tingkat kualitas hasil karya patung menggunakan adonan tepung maizena siswa kelas IX SMP Swasta Budi Dharma Tebing Tinggi berdasarkan bentuk.

2. Mengevaluasi dan mendeskripsikan secara kualitatif tingkat kualitas basil karya patung menggunakan adonan tepung maizena siswa kelas IX SMP Swasta Budi Dharma Tebing Tinggi berdasarkan komposisi.

3. Mengevaluasi dan mendeskripsikan secara kualitatif tingkat kualitas basil karya patung menggunakan adonan tepung maizena siswa kelas IX SMP Swasta Budi Dharma Tebing Tinggi berdasarkan warna.

Untuk memperoleh data yang lebih valid peneliti mengembangkan rentangan nilai sesuai tabel perhitungan Kriteria Ketuntasan Minimal (KKM) di SMP Swasta Budi Dharma Tebing Tinggi 


\section{HASIL PENELITIAN DAN \\ PEMBAHASAN \\ Hasil Penelitian \\ Untuk \\ menganalisis} eksperimen pembuatan karya patung menggunakan adonan tepung berbahan tepung maizena siswa SMP Swasta Budi Dharma, data yang digunakan adalah dari hasil observasi dan pengamatan langsung terhap karya patung siswa kelas IX SMP Budi Dharma Tebing Tinggi. Setelah terkumpul lalu dipilih dan diberi penilaiaan secara deskriptif. Berdasarkan bentuk, komposisi dan warna.

Dalam penelitian ini data diperoleh dengan mengambil sebanyak 28 sampel. Sampel dalam penelitian ini diambil dari teknik purposive sampling yaitu pengambilan sampel yang disesaikan dengan konsep yang telah ditentukan dan sesuai dengan kebutuhan penelitian. Data tersebut kemudian di deskripsikan dengan pedoman berdasarkan bentuk, komposisi dan warna pada hasil karya.

$$
\text { Sesuai dengan desain }
$$
penelitian eksperimen pembuatan karya patung menggunakan adonan tepung maizena pada Siswa/Siswi kelas IX-B SMP Swasta Budi Dharma Tebing Tinggi pad BAB III, maka pelaksanaan eksperimen berbahan tepung adalah sebagai berikut:

1. Menentukan kelas yang dijadikan subjek penelitian

2. Memperkenalkan berbahan tepung

3. Peneliti memperkenalkan serta menunjukkan berbagai macam yang dapat dibuat dari bahan tepung.
4. Menunjukkan alat serta bahan yang akan digunakan dalam proses pembuatan patung

5. Peneliti memperkenalkan serta menunjukkan langsung kepada siswa alat dan bahan apa saja yang digunakan dalam proses pembuatan dari bahan tepung.

Gambar 4. 1 Alat dan bahan

Yang digunakan dalam proses pembuatan patung berbahan tepung

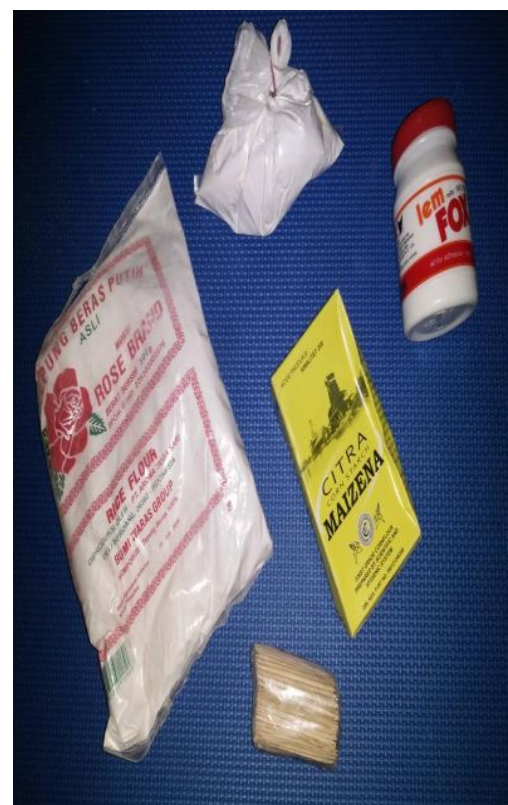

(foto : risyah nanda)

6. Mengajarkan cara pembuatan patung berbahan tepung Peneliti mengajarkan secara langsung kepada siswa cara pembuatan patung berbahan tepung. Yaitu sebagai berikut:

a. Campurkan semua tepung kedalam wadah

b. Tambahkan pengawet kedalam tepung

c. Masukan lem

d. Uleni bahan hingga tidak lengket ditangan atau kalis

e. Patung siap diwarnai dan digunakan 


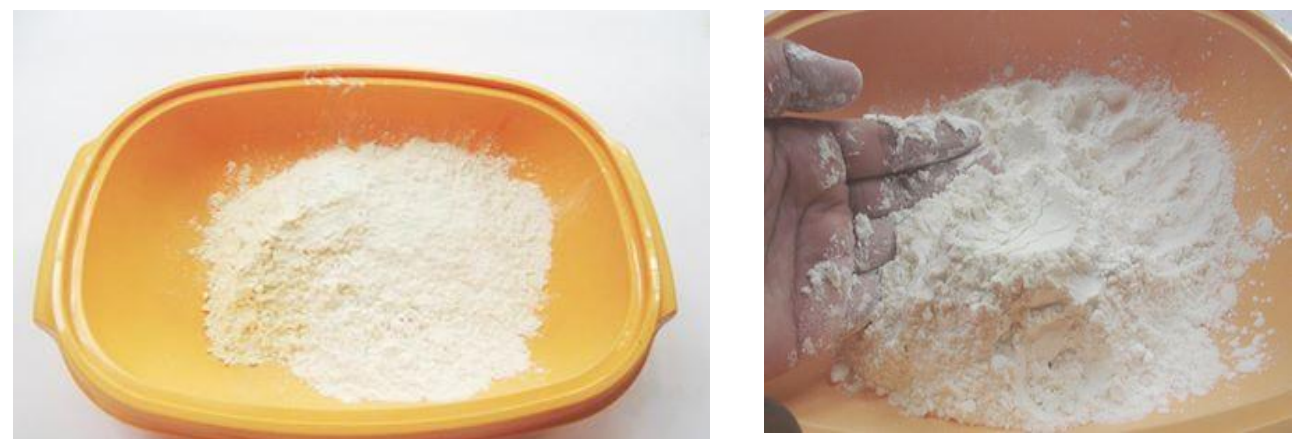

Gambar 4. 5 Tahap menguleni bahan hingga tidak lengket

Gambar 4. 2 Tahap pencampuran ditangan dan kalis semua tepung kedalam wadah

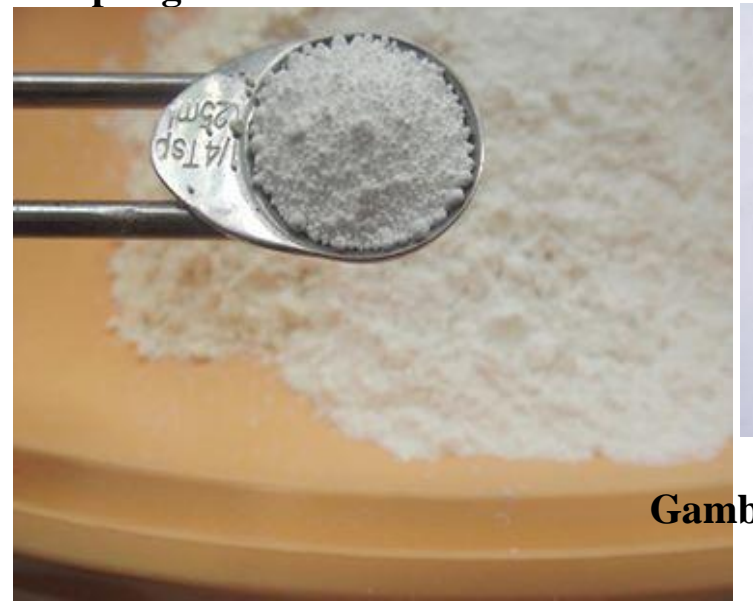

Gambar 4. 3 Tahap menambahkan pengawet kedalam tepung

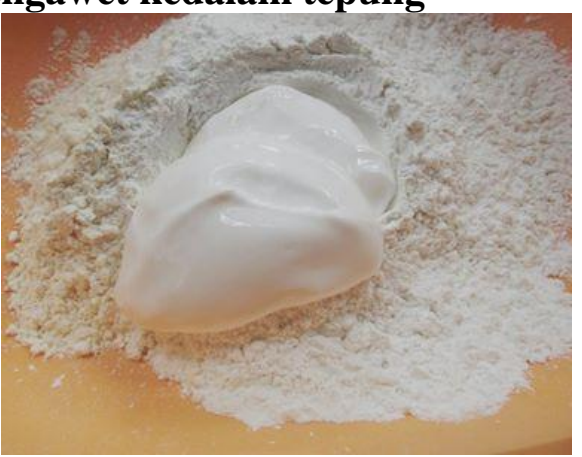

Gambar 4. 4 Tahap memasukan

Lem

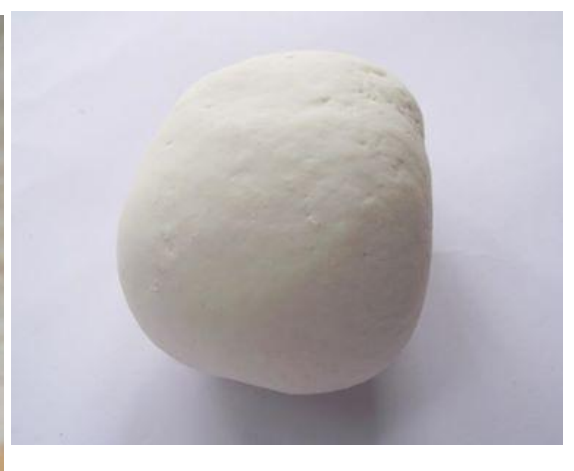

Gambar 4. 6 patung siap diwarnai dan digunakan
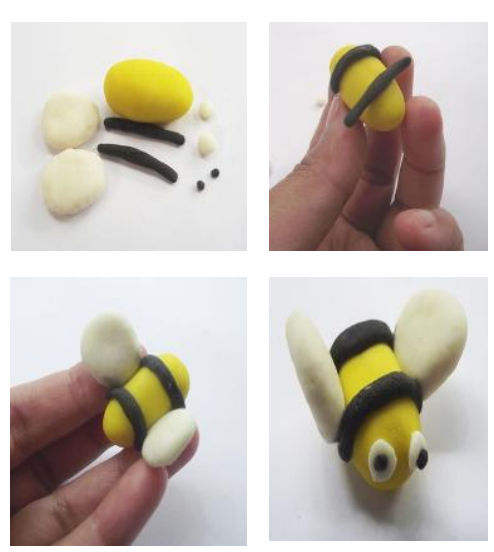

Gambar 4. 7 Hasil yang telah selesai 
7. Siswa melakukan praktek pembuatan patung berbahan tepung

Siswa melakukan praktek yang telah diajarkan dan dipraktekkan langsung oleh peneliti. Seperti pada gambar yang diatas :

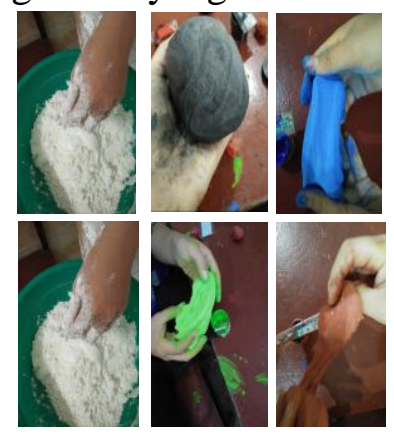

Gambar 4. 8 Siswa Sedang Memperaktekan

Cara Menyampur Bahan Yang Digunakan Serta Mewarnai Adonan

8. Mengevaluasi bentuk, warna, dan komposisi pada hasil praktek patung berbahan tepung.

9. Penilaian hasil eksperimen pembuatan karya patung menggunakan adonan berbahan tepung meizena penilaian yang dilakukan menggunakan lembar pengamatan (penilaian) yang berbentuk tabel.

\section{Pembahasan}

Setelah seluruh karya patung menggunakan adonan berbahan tepung maizena di nilai oleh penilai, selanjutnya nilai tersebut dimasukkan kedalam bentuk tabel untuk memperoleh nilai akhir. Hasil selengkapnya dapat dilihat dalam tabel berikut:

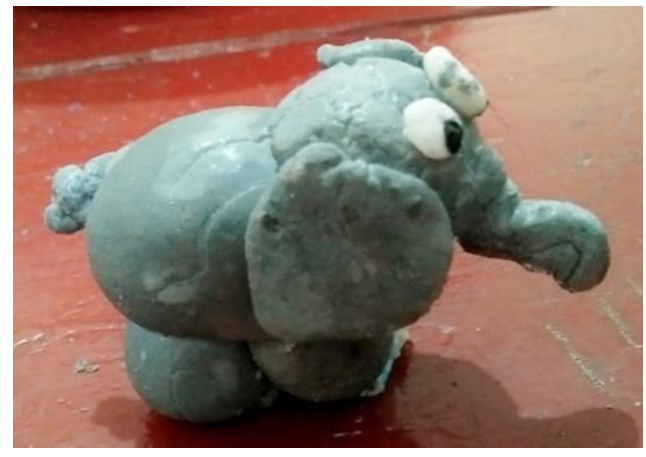

Gambar 4. 9 Karya Patung Berbahan Tepung berbentuk Gajah

Karya : Terencia Clara

Pembahasan :

Karya patung berbahan tepung berbentuk gajah ini memiliki bentuk proporsi yang ideal, bentuk yang sesuai dengan tema, dari segi komposisi karya patung ini memiliki tata susunan yang menyangkut keseimbangan, kesatuan, dan keselarasan yang baik, serta dari segi pewarnaab karya patung ini sangat menarik memiliki gelap terang yang sangat baik, kombinasi, kecerahan, kesesuaian warna dengan tema yang baik serta kreatif.

\section{KESIMPULAN DAN SARAN}

\section{Kesimpulan}

Kesimpulan hasil penelitian ini adalah

1. Berdasarkan hasil eksperimen dari penelitian dapat dinyatakan bahwa hasil eksperimen pembuatan karya patung menggunakan adonan berbahan tepung maizena pada siswa/siswi SMP Swasta Budi Dharma Tebing Tinggi sangat efektif dan dapat menghasilkan berbagai tangan seperti, patung serta berbagai macam lain dengan bentuk-bentuk yang menarik, 
serta membuat siswa lebih kreatif lagi dalam pemanfaatan bahan-bahan yang dapat dimanfaatkan di lingkungan sekitar.

2. Siswa dapat mengetahui perbedaan bahan yang digunakan dalam membuat karya patung menggunakan dua bahan utama yang berbeda yaitu berbahan utama adonan tepung dan berbahan utama tanah liat, siswa juga dapat mengetahui proses pembuatan karya patung berbahan tepung yaitu mulai dari proses pencampuran tepung dengan lem, pengawetan, proses membentuk dan proses finishing (pewarnaan) dan proses pembuatan karya patung menggunakan tanah liat yaitu dari mulai mengaduk aduk tanah liat dengan tangan/membanting bantingkan tanah liat di lantai hingga menjai tanah liat yang sangat elastic setelah menjadi elastis,tanah liat sudah bisa untuk di buat sebagai patung.

3. Hasil eksperimen pembuatan karya patung menggunakan adonan berbahan tepung maizena yang dibuat oleh siswa/siswa SMP Swasta Budi Dharma Tebing Tinggi ini memiliki unsur bentuk yang menarik sesuai dengan tema, proporsi yang baik, memiliki kombinasi warna yang baik, serta kecerahan warna yang baik dalam tata susunan dan keselarasannya dibandingkan dengan hasil karya patung menggunakan tanah liat yang membuat hasil karya siswa cenderung memiliki warna yang sama dikarena kombinasi warna tidak terlihat baik dan tidak sesuai dengan tema, hal ini disebebkan karena pada proses pembuatan patung berbahan tanah liat siswa dituntut agar menghasilkan adonan yang elastis dengan cara mengaduk-aduk dan membanting-banting tanah sampai dapat dibentuk menjadi sebuah patung. Dalam proses ini siswa kurang mampu mengaplikasikannya sehingga menghasilkan tanah liat yang kurang baik sehingga mempengaruhi hasil karya.

\section{Saran}

Saran dari peneliti ini adalah :

1. Untuk pihak sekolah maupun dinas pendidikan diharapkan untuk dapat lebih mengembangkan dan memanfaatkan bahan-bahan sekitar yang bisa dijadikan bahan pembuatan kerainan- bagi siswa/siswi seperti contohnya tepung, sehingga pengetahuan siswa dapat bertambah lebih dengan banyaknya mcam bahan yang bisa dimanfaatkan sebagai bahan .

2. Untuk masyrakat penelitian ini dapat dijadikan referensi peluang usaha baru dan sumber pemasukan dalam bidang tangan.

3. Untuk peneliti selanjutnya yang ingin meneliti tentang karya patung berbahan tepung supaya memperluas dan mengembangkan 
yang bisa di buat dari bahan dasar tepung

\section{DAFTAR PUSTAKA}

Ali, M, 1993. Stategi penelitian pendidikan. Bandung PT Angkasa Raya

Arikunto. 2013. Prosedur Penelitian Suatu Pendekatan Praktik, Jakarta : Rineka Cipta.

Aryadi, Muhammad. 2004. Tangan dan kesenian, Jakarta : Grafindo.

Bahari, Nooryan. 2008. Kritik Seni, Yogyakarta : Pustaka Pelajar.

Djamarah, Zain. 2006. Strategi Belajar Mengajar, Jakarta : Rineka Cipta.

Garha, Oho. 1977. Pendidikan Kesenian Seni Rupa Program Spesialisasi I. Jakarta : Cv Angkasa.

Margono. S. 2005. Metodologi penelitian Pendidikan.Jakarta : Rineka Cipta

Nasbahry,.Couto. 1993. Seni Rupa, Teori dan Aplikasi. Padang; Unp Press
Raharjo, Timbul. 2009. Bisnis Seni Bikin Londho Keranjingan. Yogyakarta : Program Pasca Sarjana ISI.

Stephani. 2010. 30 Menit Membuat Kreasi dari Patung. Jakarta : Demedia

Sugiyono. 2011. Metode Penelitian Pendidikan. Cetakan Ketujuh. Bandung : Alfabeta.

Susanto Mikke. 2011. Diksi Rupa, Yogyakarta. DictiArt.

Soeroto. 1993. Strategi Belajar Mengajar. Jakarta : Rineka Cipta

Sumanto. 2006. Pengembangan Kreatifitas Seni Rupa Anak Sekolah Dasar. Jakarta : Direktur

Yudoseputro, Wiyoso. 1983. Seni Indonesia. Jakarta : Departemen pendidikan Dan Kebudayaan.

Zuriah, Nurul. 2006. Metodologi Penelitian Sosial dan Pendidikan. Jakarta: Bumi Aksara

http://id.wikipedia.org/wiki/tepung, (diakses 10 Juni 2015). 